\title{
Commentary on the article "Diaphragm perforation during laparoscopic left adrenalectomy” of Stanisław Głuszek, Monika Kozłowska
}

Videosurgery and other miniinvasive techniques 2009; 4 (4): 168-170

\author{
Maciej Otto \\ Department of General, Vascular and Transplant Surgery, Medical University of Warsaw, Warsaw, Poland
}

Videosurgery and other miniinvasive techniques 2010; 5 (1): $42-43$ DOI: 10.5114/wiitm.2010.13607

The presented research belongs to the relevant and important kind of publications which contain important and "embarrassing" issues such as surgical complications. That issue has remained difficult to discuss.

The complications accompanying surgical procedures often become adverse, unwanted effects of invasive treatment. Early recognition allows us to take appropriate measures so that we can reverse or repair existing problems. Consequently the patient may be fully recovered. The evaluated presentation concerns such relevant matters, even though it concerns initially mini-invasive procedures.

The complications arising from videoscopy/laparoscopy are related to the use of mini-invasive techniques and to the kind of performed operations.

The particular problems for videoscopy/laparoscopy are caused by insufflations of $\mathrm{CO}_{2}$ (to produce a pneumoperitoneum), insertion of the first trocar, stabilization of all trocars, and obtaining a clear and safe field of vision, which enables correct anatomical identification. Other specific problems are related to technical aspects concerning the use of medical devices.

The postoperative surgical complications depend on the type of surgery that was performed by laparoscopy. The percentage of such unwanted cases varies.

If we compare these findings to the number of complications after open surgery, we will assess noninvasive methods reliably.
One of the common criteria is the incidence of biliary tract injury associated with laparoscopic cholecystectomy. Currently it is reported to be 2.5 times that of the open procedure. The rate varies across continents: in the USA $0.5-2.7 \%$ vs. $0.33 \%$ in Europe.

According to A. Tocchie, 30-day mortality after laparoscopic cholecystectomy occurs in $2.2 \%$ of all cases. Therefore, the frequency of occurrence of biliary tract damage is about $0.1-2 \%$ in the laparoscopic method and $0-0.7 \%$ in classic cholecystectomy. That is why the summation of the number of complications which results from laparoscopic methods and technical aspects dependent on the type of operation seems to be erroneous as well as quotation of such pieces of information while discussing laparoscopy performed in adrenal gland diseases.

In adrenal gland surgical procedures complications are connected with injury of the parenchyma organs (liver, spleen, pancreas) or large vessels and very rarely with diaphragm injuries which can result in intraoperative occurrence of tension pneumothorax. This is regardless of chosen operation method, open or videoscopic. Nevertheless, severe complications during laparoscopic adrenalectomy are very rare (inferior vena cava damage which caused liver transplantation, ligation of hepatic artery or ureter, kidney removal caused by wrong anatomical identification or normal

Address for correspondence:

Prof. Maciej Otto, Department of General, Vascular and Transplant Surgery, Medical University of Warsaw, 1a Banacha St., 02-097 Warsaw, phone: +48 2259924 67, fax: +48 2259914 68, e-mail: maciej.otto@wum.edu.pl 
adrenal gland resection leaving a richly vascularized tumour in its area) [1, 2].

According to the Japanese literature, intraoperative complications in laparoscopic adrenalectomy appear in about $9 \%$ intraoperatively, in $6 \%$ postoperatively and conversion in 3.5\% of cases [3]. In English literature complications in adrenal gland surgery assessed before and after introducing laparoscopy are found in $25.2 \%$ of cases in laparoscopic adrenalectomy $(\mathrm{AL}) \mathrm{vs}$. $10.9 \%$ in classic adrenalectomy (AC). Bleeding more often happens in laparoscopy, respectively 4.7 vs. $3.7 \%$. However, more significant is the frequency of occurrence of injury of the parenchymal organs in the open method (2.4 vs. 0.7\%), especially the spleen; more frequent problems with wound (6.9 vs. 1.4\%), lung complications (5.5 vs. $0.9 \%$ ), circulatory complications (1.6 vs. $0.3 \%$ ) and infections (5.8 vs. $1.6 \%$ ). There are no relevant differences in occurrence of neurological, gastrointestinal and thromboembolic complications. Morbidity is about $0.3 \%$ in $\mathrm{AL}$ and $0.9 \%$ in AC $[4,5]$. In our material (over 500 laparoscopic adrenalectomies) intraoperative complications occurred in $0.7 \%$ of all cases, postoperative in $2.6 \%$ and conversions in $2.8 \%$, morbidity: $0.02 \%$ [6-9].

Because of the wide acceptance of the laparoscopic method in surgical techniques and its increasing popularity (which is being proved by reports about the developing method of access through a natural foramen of the body) the present work is even more important. It makes the possibility of occurrence of unpredictable complications visible and emphasizes the role of the surgeon's experience and skills in classic surgery. There is a crucial point in discussion about training in mini-invasive methods in specialization programmes. It is vital to find a counterbalance in young surgeons' education. Not only knowledge about aspects of mini-invasive operations, but also experience and familiarity with open surgery are decisive for the results of laparoscopic surgeries. It may be crucial in the case of laparoscopic complications, when a surgeon of the "old school" is indispensable. Considering causes of diaphragm damage, which was a starting point for following complications, it may awake doubts concerning the suggestion of not using monopolar coagulation during laparoscopy. I considered that this kind of electrocoagulation is no longer used in such operations and bipolar devices are more common. The equipment status of coagulation (electrical leakiness) may be a problem in this case. Probably the rule of using disposable instruments in laparoscopy should be respected. Damage of the isolated part of the device outside of the visual field of the camera may cause uncontrolled thermal injuries unrecognized during the operation.

I would like to congratulate the authors once again. The work is interesting, valuable and addresses the ever-important problem of complications in a clear way. At the same time, it confirms that early and proper diagnosis may prevent such consequences.

\section{References}

1. Brunt LM. The positive impact of laparoscopic adrenalectomy on complications of adrenal surgery. Surg Endosc 2002; 16: 252-7.

2. Tessier DJ, Iglesias R, Chapman WC, et al. Previously unreported high-grade complications of adrenalectomy. Surg Endosc 2009; 23: 97-102.

3. Nakagawa K, Murai M. Laparoscopic adrenalectomy: current status with a review of Japanese literature. Biomed Pharmacother 2002; 56: 107-12.

4. Strebel RT, Muntener M, Sulser T. Intraoperative complications of laparoscopic adrenalectomy. World J Urol 2008; 26: 555-60.

5. Poulouse BK, Holzman MD, Lao OB, et al. Laparoscopic adrenalectomy: 100 resections with clinical long-term follow-up. Surg Endosc 2005; 19: 379-85.

6. Otto M, Dzwonkowski J. Powikłania zakrzepowo-zatorowe w chirurgii małoinwazyjnej nadnerczy - profilaktyka przeciwzakrzepowa. Videosurgery and other miniinvasive techniques 2007; 2: 43-7.

7. Otto M, Nazarewski S, Szostek G, et al. Adrenalektomia laparoskopowa: dostęp boczny przezotrzewnowy - metoda i trudności śródoperacyjne. Videochirurgia 2002; 7: 15-20.

8. Otto M, Szostek G, Dzwonkowski J, et al. Ocena adrenalektomii laparoskopowej. Videochirurgia 2002; 7: 21-5.

9. Otto M, Dzwonkowski J, Ciąćka T, et al. Ponad 10-letnie doświadczenia w leczeniu zmian nadnerczowych metodą laparoskopową z dostępu bocznego przezotrzewnowego. Pol Przegl Chir 2008; 89: 881-94. 